\title{
The shifting conceptualization of elder abuse in the United States: from social services, to criminal justice, and beyond
}

A variety of forces have shifted the conceptualization of elder abuse over time to where it is almost unrecognizable when compared to its original conceptualization. The field has adopted or embraced whatever social problem is in vogue in an attempt to elevate elder abuse to a recognizable social problem that to date has eluded the field. This paper traces the various influences on the shifting conceptualizations of elder abuse and how those conceptualizations have shaped society's response. The paper concludes by suggesting that multiple conceptualizations can and must co-exist, a framework which is consistent with the multidisciplinary team approach becoming prevalent in the field.

\section{0s: conceptualizing older adults in need of protection}

\section{The rise of protective services}

More than two decades prior to the identification of elder abuse, protective services for vulnerable older adults was instituted. The development of protective services was facilitated by the enactment of the Social Security Act of 1935 which changed the face of the elderly population by the 1950 s by drastically reducing the number of older Americans that were financially and/or residentially dependent upon their family (Kutza, 2005). For example, the percentage of elderly widows living alone rose from $18 \%$ in 1940 to $62 \%$ in 1990 , while the percentage living with adult children declined from $59 \%$ to $20 \%$ (McGarry and Schoeni, 2000). Consequently, there was a tremendous increase in the number of older adults living alone. At the same time, Americans were living longer. In the 1930s, the average life expectancy for males and females was 58.1 and 61.6 years, respectively. By 1950, life expectancy had increased to 65.6 and 71.7 years for males and females, respectively (CDC, 2011). This longer life expectancy contributed to an increase in the elderly population. Between 1950 and 1970, the elderly population increased from $8.1 \%$ to $9.8 \%$ (Hobbs, 1996).

America of the 1950s experienced tremendous prosperity (Chevan, 1989). This allowed the juxtaposition of the poor and the affluent, exposing the wanting among poor and vulnerable older adults. The increased visibility of issues germane to older Americans alerted public welfare officials to a large number of elderly citizens who were experiencing functional limitations while living on their own (Wolf, 2003). This realization motivated professionals to find remedies for the problems faced by vulnerable older adults.

Concern about the increasing numbers of very old, impaired, and impoverished elderly individuals - a condition later termed self-neglect - led to the formulation of new government programs referred to as protective services units in the 1950s (Brownell and Abelman, 1998; Wolf, 2003), fortuitously at a time when society was relatively prosperous and willing to fund such projects (Estes, 1982). Amendments to the Social Security Act in 1962 authorized payments to states to establish protective service units (Teaster et al., 2010). The first protective services legislation contained in the Older American's Act of 1965 provided federal funding to states to support community planning, social services, and research and development projects for individuals aged 60 years and older, but particularly targeted those with the greatest social and economic need (O'Shaughnessy, 2008). These units focused on identifying and meeting the day-to-day needs of vulnerable older adults, and in some cases initiating legal proceedings such as guardianship.

Initially, interest in protective services flourished. In 1966, Congress funded six demonstration projects to evaluate the utility of the protective services units established in several states, which constituted the first (and last) empirical examination of the effectiveness of protective services. Unexpectedly, the study revealed that older adults receiving these services had higher nursing home placements and higher mortality rates than older adults receiving traditional services (Blenkner et al., 1971). This is not surprising in hindsight as protective services vigorously promoted intervention in the form of institutionalization as a solution to the destitution and isolation of their elderly clients (Wolf, 2003).

Thus, the conceptualization of the problem - that impoverished and vulnerable older adults were in 
need of protection - resulted in a policy solution designed to address impoverishment and functional limitations: institutionalization (and where appropriate, guardianship). Institutionalization was perceived as the best alternative for ensuring adequate food, shelter, and functional assistance for these individuals. Importantly, then, protective services as it was initially conceptualized was not designed to address elder abuse, but rather, selfneglect.

Over time, protective services became disparaged. Criticisms included the costliness of these programs, the research demonstrating that such intervention could be counterproductive and deleterious to the welfare of elderly citizens, stigma associated with public assistance, and importantly, the perception that such interventions infringed on the civil rights of elderly Americans (Wolf et al., 1998). As a consequence, interest in the use of protective services waned, along with an accompanying decrease in funding for such programs.

\section{0s: conceptualizing elder abuse as caregiver stress}

The "discovery" of elder abuse, and the transition of protective services to adult protective services, occurred within the context of the discovery of child abuse. Therefore, the discovery of child abuse is briefly reviewed.

\section{Child abuse}

Prior to the recognition of elder abuse, child abuse had been gaining attention and in important ways was a precursor to the "discovery" of elder abuse. Child abuse was "discovered" in 1962 with the publication of Kempe's Battered Child Syndrome (Kempe et al., 1962). With the power and authority of physicians raising the profile of child abuse (along with other important factors), society rallied around the recognition of child abuse (Parton, 1979). While initially conceptualized as stemming from parental psychopathology (Kempe et al., 1962; Spinetta and Rigler, 1972), child abuse (predominately child physical abuse at the time) was quickly radically re-conceptualized as an issue associated with parental stress (Gelles, 1973), and then more comprehensively refined into an ecological model which placed parental culpability in a larger societal context (Belsky, 1993). For example, prominent at the time was the belief that every parent was vulnerable to abusing their children under the right circumstances (Friedrich and Boriskin, 1976). Child abuse was conceptualized as resulting from the stresses of parenting. Therefore, what families needed was assistance in managing the challenges associated with child rearing. Given this conceptualization of child abuse, the policy solution was the provision of social services for families experiencing stress due to lack of money, housing, nutrition, parenting skills, etc. Regardless of the source of stress, the focus of intervention was on the parents. The approach was less on culpability and more on helping. Importantly, in the beginning at least, the problem of child abuse was primarily situated in the parent-child relationship and only in the 1980s did child sexual abuse emerge and considerably expand the range of individuals who could abuse children, thus requiring a different conceptualization of the problem.

With the recognition of child abuse, federal and state governments were compelled to act (Hafemeister, 2010). By 1963, the Children's Bureau had promulgated a model child abuse reporting law that mandated that physicians report suspected physically abused children to law enforcement agencies. By 1967, every state had adopted a mandatory child abuse reporting statute. Through a confluence of events, including media attention (Parton, 1979), child abuse had become a legitimate social problem, reflected in the passage of the Child Abuse Prevention and Treatment Act (CAPTA) of 1974.

\section{Elder abuse}

The timing of CAPTA was impeccable. Recall that up to this point, attention toward older adults had been focused on self-neglect. However, in the wake of the discovery of child abuse, recognition of elder abuse emerged. Physicians are credited with first identifying elder abuse. Although elder abuse has been recognized throughout history (Gorbien and Eisenstein, 2005; Teaster et al., 2010), Burston is generally identified as writing the first published account of elder abuse in a scientific journalthe British Medical fournal - which appeared in a 1975 letter entitled "Granny Battering." However, Robert Butler wrote the first account of elder abuse in the USA in Why Survive?: Being Old in America (Butler, 1975).

Early research on elder abuse took place primarily in the field of gerontology. With the very recent recognition of elder abuse, the field was still primarily focused on vulnerable and impoverished older adults. Studying this population, Steinmetz (1978) observed that some older adults were being abused by their caregivers. She concluded that, similar to child abuse, elder abuse (primarily physical abuse at the time) stemmed from the stress of caring for vulnerable (functionally impaired) older adults. (Note also that similar to child abuse, 
the abusive situation was limited to a victim and a caregiver). Steinmetz's (1978) research catapulted elder abuse into the public sphere. Caregiver stress theory, as it was labeled, dominated the field for the next two decades.

In the context of their waning popularity, advocates for protective services - a system historically designed to promote the well-being of functionally impaired and impoverished elderly persons - took advantage of these reports and research to call for expanding the use of protective services to respond to the needs of elder abuse victims. Harbison and Morrow (1998) note that when elder abuse emerged in the 1970s, powerful interest groups, such as service providers, had a motive for depicting older adults as frail and dependent (p. 697). Providers reasoned that the structure and mechanisms of protective services were already in place, as well as an acceptable explanatory model (i.e. caregiver stress). Therefore, the protective services model was retained and adopted without much consideration as to its appropriateness in responding to elder abuse.

This conceptualization of elder abuse as a problem of caregiving, similar to that of child abuse, resonated with Congress and the media. In 1975, Congress amended the Social Security Act to include Title XX, which required states to enact protective services for abused or neglected elders (Teaster et al., 2010) and in 1987 Congress amended the Older Americans Act (Title I) to address the protection of older adults from abuse, neglect, and exploitation (Greenlee, 2011). As child abuse already had a conceptual framework that was similar to that of elder abuse, state policy makers simply crafted elder abuse protective services statutes after child protective services statutes (Glick, 2005; Hafemeister, 2010), in some states literally restating the problem from "adults in need of protective services" to "victims of elder abuse, neglect, and exploitation" (Kohn, 2009). Thus, during the 1980 s protective services units became adult protective services units as they are widely known today (for statutory reviews, see Jirik and Sanders, 2014; Jackson, 2015). In addition, due to the perceived success of child abuse mandatory reporting laws (Hafemeister, 2010), and in anticipation of federal funding, states began passing elder abuse mandatory reporting laws crafted after child abuse mandatory reporting laws (Kohn, 2009), a policy that remains controversial to this day (Glick, 2005).

Evidence that the caregiver stress model had permeated the public consciousness is reflected in a 1981 federal report stating that " $[M]$ ost experts do appear to believe ... that a major precipitating factor [of elder abuse] is family stress" (Garfield,
1991). Given this conceptualization (caregiver stress), the policy solution was the provision of social services for caregivers to reduce their stress (e.g. respite care for caregivers). However, there was no federal elder abuse legislation or a widelyheld recognition that elder abuse was a serious social problem.

\section{The 1990s: conceptualizing elder abuse as a crime}

The conceptualization of elder abuse changed radically in the 1990s. The historical underpinnings of this shift resulted from the substantial gains made by the battered women's movement, and subsequently, the recognition of family violence, at the time two distinct concepts. Domestic violence as it was initially conceptualized in the 1970s was vastly different than the conceptualization of elder abuse in the 1970s and consequently the two fields shared little in common. That would change radically in the coming decades.

\section{Battered women's movement}

Gaining public attention during the 1970s was the battered women's movement, an offshoot of the women's movement. However, its initial influence on elder abuse is more circumspect than that of child abuse.

Following on the heels of the discovery of child abuse was the rise of the battered women's movement and the discovery of domestic violence. England is credited with first recognizing battered women with the publication of Scream Quietly or the Neighbors will Hear in 1974 (Pizzey, 1974). The signal was quickly transmitted to America where battered women's shelters had existed informally in communities across the country, but without public attention or organization (Miccio, 2005; Lehrner and Allen, 2009). In America, the 1970s witnessed the rise of soon-to-become powerful grassroots advocacy groups (Schechter, 1982). Populated by a mix of battered and professional women (e.g. lawyers), the battered women's movement conceptualized domestic violence as a problem of structural gender inequality (patriarchy) in society (Dobash and Dobash, 1979). The problem was not with the victims of domestic violence, but with a society and its laws that permitted and promoted the abuse of women. The response, therefore, required vast macro-level changes (laws, institutions), denigrating and eschewing any microlevel conceptualization of domestic violence.

Among the many factors believed to contribute to patriarchy was law enforcement's lack of response in domestic violence calls (Miccio, 2005), an 
institution believed to be in collusion with other political structures that permitted the abuse of women. Indeed, law enforcement at that time was being trained to "mediate" domestic disputes rather than to actively intervene (Miccio, 2005). Lawsuits were initiated across the country, including the prominent Thurman v. City of Torrington, Conn., compelling changes in law enforcement policies (Zorza, 1992). Simultaneously, research demonstrating the benefits of arrest had been published (Sherman and Berk, 1984), bolstering the advocate's position, although discounting subsequent research that might have tampered enthusiasm for arrest policies (Sherman, 1992). Although the Movement's demands were much broader than changes in the criminal justice system, the Movement and a criminal justice system response became conflated, with batterer accountability a hallmark of the Movement (Gondolf, 2011).

Advocates were tenacious in their demands. Twenty years of unabridged passion and advocacy culminated in the passage of the Violence against Women Act (VAWA) of 1994, validating domestic violence as a social problem. Importantly, the VAWA was embedded in the Violent Crime Control and Law Enforcement Act of 1994, the implication being that the federal government conceptualized domestic violence as a crime. The battered women's movement was now perceived as wildly influential and successful (Miccio, 2005; Buzawa et al., 2012). However, the Movement stalwartly avoided mandatory reporting as a policy solution as such policies were perceived as dangerous for women and overtly paternalistic (Han, 2003; Hafemeister, 2011).

\section{Family violence}

Simultaneously competing for attention in this arena was the family violence model espoused by sociologists such as Straus and Gelles (1986). These scholars were vilified by the battered women's movement for promoting a narrative in which domestic violence could best be understood as a form of family violence - difficulty resolving conflicts - rather than resulting from patriarchy. Perhaps even more egregious according the battered women's movement, Straus and Gelles (1986) argued that both males and females perpetrated violence against their spouses/partners, sometimes referred to as gender symmetry. In addition, Gelles (1985) observed that offenders were often afflicted with various forms of psychopathology, distasteful to the battered women's movement who perceived such characterizations as excuses.
The battered women's movement had made tremendous headway in terms of demanding a law enforcement response such that by the 1990s arrest of offenders was widely (albeit unevenly) practiced (Sherman, 1992; Miccio, 2005) regardless of how advocates or scholars conceptualized the problem. These two predominant views of domestic violence have had a rancorous co-existence, but coalesced to a large extent around a criminal justice response. While still somewhat contentious, today there is greater recognition of the heterogeneity subsumed under the rubric of domestic violence (Kelly and Johnson, 2008).

\section{Elder abuse transitions to a criminal justice framework}

Prior to the 1990s, elder abuse generally had not been considered a crime (Krienert et al., 2009). An important philosophical shift in the conceptualization of elder abuse occurred in the 1990s, underpinnings that were present a decade earlier. Groundbreaking research by Georgia Anetzberger (1987) and Karl Pillemer (1985) began to challenge the largely-held assumptions underlying the caregiver stress model. This research revealed that elder abuse differed in meaningful ways from child abuse, shifting the focus from the victim's role in elder abuse (i.e. their vulnerability and difficulty in caring for them) to that of the abuser (psychopathology model), transforming the conceptualization of elder abuse from a problem similar to child abuse to a problem more closely aligned with family violence (Wolf et al., 1998). As the family violence model already had a criminal justice framework, the inclusion of elder abuse as a family violence issue transformed elder abuse from a social services issue to a criminal justice issue (Wolf et al., 1998).

The impact of this early research in reshaping the field of elder abuse cannot be understated, although a confluence of events facilitated the adoption of this new perspective. The criminal justice shift was nested in a greater societal upheaval at the time, with the late 1980s and early 1990s bearing witness to soaring crime rates (BJS, 2002) and an accompanying "get tough on crime" response (Mauer, 1999). This transition was further facilitated by the public's shifting stereotype of the elderly from vulnerable to relatively well-off by the late 1980s (Hooyman and Kiyak, 1988; Harbison and Morrow, 1998). Harbison (2000) describes the tension between viewing older adults as frail and dependent on the one hand and the emerging research finding older adults "successfully" aging, with some younger adults voicing resentment at having to pay for programs for older adults who are 


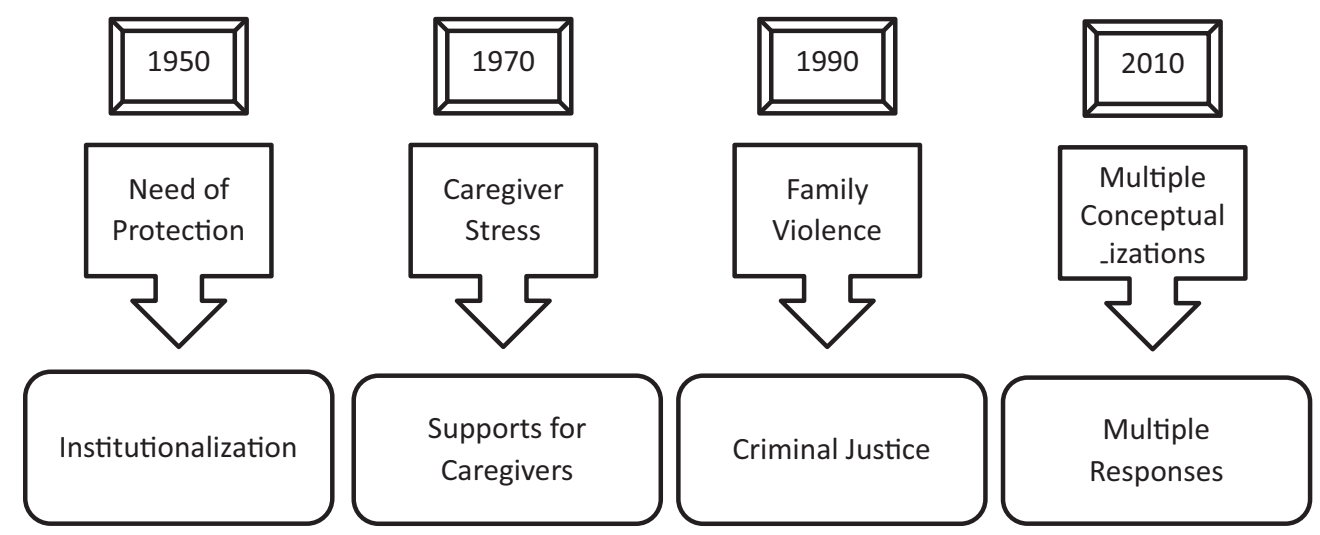

Figure 1. Conceptualizations of elder abuse over time.

relatively well-off and physically fit (p. 64). Thus, older Americans who were victims of abuse were not "in need of assistance" but rather were entitled to justice.

This criminal justice conceptualization was cemented with the launching of the elder justice movement. In 2002, the US Department of Justice became involved in elder abuse through the Department's Nursing Home Initiative, which began funneling funds to the National Institute of Justice for elder abuse research (Connolly, 2012a). The phrase elder abuse was supplanted by elder justice, reflecting the Department's conceptualization of elder abuse as a crime. The new terminology had the very practical effect of expanding the concept and explicitly wrapping elder abuse in a criminal justice sheath perceived to resonate with a constituency that is broader than a social services orientation engenders. Scholars argue that this criminal justice transformation is responsible for elder abuse receiving legitimacy in the 1990s that affiliation with public welfare or social services failed to provide (Wolf et al., 1998; Krienert et al., 2009). First introduced in 2002, the Elder Justice Act was passed in 2010. However, elder abuse still has not reached the prominence of a recognized social problem.

\section{0s: the expanding conceptualizations of elder abuse}

The field may have stagnated except for the infusion of new funds to the elder justice research field administered by the National Institute of Justice. Now that funding sources were available, disciplines other than social services expressed an interest in elder abuse (Anetzberger, 2011). This had the effect of imbuing the field with fresh, new perspectives across a number of disciplines, each with its own conceptualization of elder abuse. Geriatricians such as Mark Lachs had been advocating for conceptualizing elder abuse as a public health issue since the 1990s (Lachs, 1996), while Laura Mosqeda emphasizes the medical implications of elder abuse (Gibbs and Mosqeda, 2014), and XinQi Dong conceptualizes elder abuse as a human rights issue (Dong et al., 2014). Legal scholars have attempted to frame elder abuse as a human (Herring, 2012; Westwood, 2012) or civil (Kohn, 2009; Connolly, 2012b) rights issue. Some activists have conceptualized elder abuse as a gendered issue (Somers, 2013). Scholars have continued to conceptualize elder abuse as a crime (Payne, 2011), a form of family violence (Acierno et al., 2010), and a social services issue (Wangmo et al., 2014). Although some scholars have abandoned the caregiver stress model (Rathbone-McCuan, 2000), APS caseworkers continue to embrace this conceptualization (Mixson, 2010). Clearly, each conceptualization has implications for the way in which society responds.

And so sits elder abuse in 2015, 40 years after its discovery, at the crossroads between a historical reliance on social services and a newer and more politically savvy criminal justice orientation, each of which was borrowed from other fields. In addition, there is now an ever-expanding collection of conceptualizations. It is time for these siloed conceptualizations to cease competing with one another for prominence (depicted in Figure 1) and allow for their simultaneous existence (depicted in Figure 2). Recognition of the diversity and range of complexity of elder abuse cases supports the assertion that forms of elder abuse are sometimes a crime, sometimes a medical issue, sometimes a social services issue, and sometimes a combination of these and more. Consequently, a one-size-fits-all response is unacceptable (Jackson, 2014). Adult protective services remain primarily responsible for responding to elder abuse, but they are no longer alone. As disciplines recognize the 


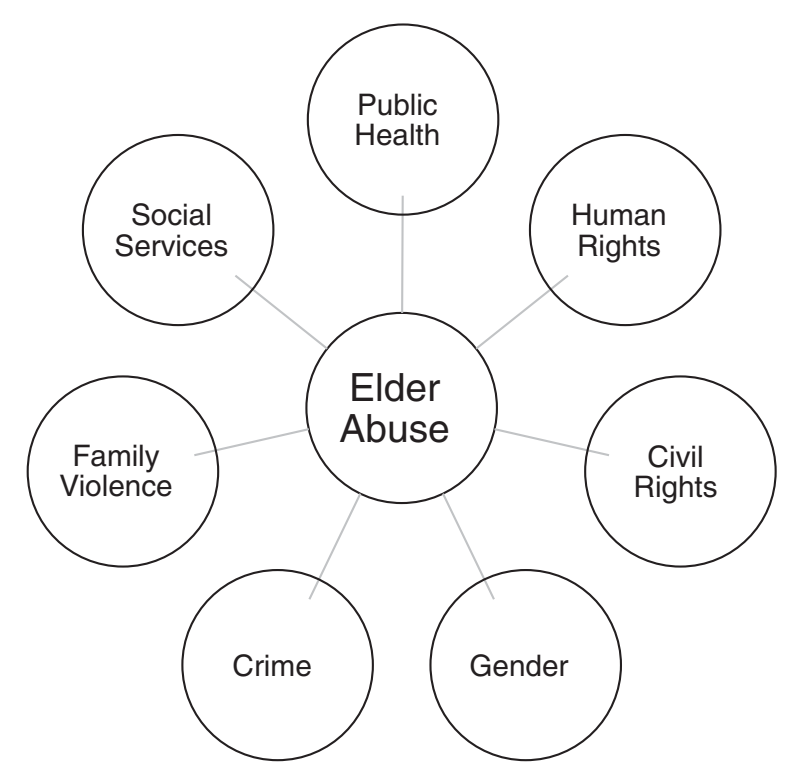

Figure 2. Co-existing conceptualizations of elder abuse.

multidimensional nature of elder abuse (Payne, 2002), there is greater interest in responding with a multidisciplinary team approach (Daly and Jogerst, 2014; Schneider et al., 2010). Our conceptualization of elder abuse should reflect this shift.

\section{Conflict of interest}

None.

\section{SHELLY L. JACKSON}

Institute of Law, Psychiatry and Public Policy, PO Box 800660, University of Virginia, Charlottesville, VA Email: slj4u@virginia.edu

\section{References}

Acierno, R. et al. (2010). Prevalence and correlates of emotional, physical, sexual, and financial abuse and potential neglect in the United States: the national elder mistreatment study. American Fournal of Public Health, 100, 292-297.

Anetzberger, G. (2011). The evolution of a multidisciplinary response to elder abuse. Marquette Elder's Advisor, 13, 107-128.

Anetzberger, G. J. (1987). The Etiology of Elder Abuse by Adult Offspring. Springfield: Charles C Thomas.

Belsky, J. (1993). Etiology of child abuse: a developmental ecological analysis. Psychological Bulletin, 114, 413-434. doi: 10.1037/0033-2909.114.3.413.

Blenkner, M., Bloom, M. and Nielson, M. (1971). A research and demonstration project of protective services. Social Casework, 52, 483-499.
Brownell, P. and Abelman, I. (1998). Elder Abuse: Protective and Empowerment Strategies for Crisis Intervention. New York: Springer.

Bureau of Justice Statistics [BJS] (2002). Age Patterns in Violent Victimization, 1976-2000. BSJ Crime Data Brief (February 2002 NCJ 190104). Washington, DC: BJS, OJP, USDOJ.

Burston, G. R. (1975). Granny battering. British Medical fournal, 3, 592.

Butler, R. N. (1975). Why Survive?: Being Old in America. Oxford: Harper \& Row.

Buzawa, E. S., Buzawa, C. G. and Stark, E. (2012). Responding to Domestic Violence: The Integration of Criminal fustice and Human Services, 4th edn. Thousand Oaks: Sage.

Centers for Disease Control and Prevention [CDC] (2011). Table 22. Life Expectancy at Birth, at Age 65, and at Age 75, by Sex, Race, and Hispanic Origin: United States, Selected Years 1900-2010. National Center for Health Statistics, Centers for Disease Control and Prevention. http://www.cdc.gov/nchs/data/hus/2011/022.pdf; last accessed 15 October 2014.

Chevan, A. (1989). The growth of home ownership: 1940-1980. Demography, 26, 249-266.

Connolly, M. T. (2012a). High-cost blind spot. Public Policy E Aging Report, 22, 8-16.

Connolly, M. T. (2012b). Policy update: how change happens. Temple Political and Civil Rights Law Review, 21, 329-336.

Daly, J. M. and Jogerst, G. J. (2014). Multidisciplinary team legislative language associated with elder abuse investigations. Fournal of Elder Abuse E Neglect, 26, 44-59. DOI: $10.1080 / 08946566.2013 .782783$.

Dobash, R. P. and Dobash, R. E. (1979). Violence Against Wives: A Case Against the Patriarchy. New York: Free Press.

Dong, X., Chen, R. and Simon, M. A. (2014). Elder abuse and dementia: a review of the research and health policy. Health Affairs, 33, 642-649. doi: 10.1377/hlthaff.2013.1261.

Estes, C. (1982). Austerity and aging in the United States: 1980 and beyond. International fournal of Health Services, $12,573-584$.

Friedrich, W. N. and Boriskin, J. A. (1976). The role of the child in abuse: a review of the literature. American fournal of Orthopsychiatry, 46, 580-590.

Garfield, A. S. (1991). Elder abuse and the States' adult protective services response: time for a change in California. Hastings Law fournal, 42, 859937.

Gelles, R. J. (1985). Family violence. Annual Review of Sociology, 11, 347-367.

Gelles, R. J. (1973). Child abuse as psychopathology: a sociological critique and reformulation. American fournal of Orthopsychiatry, 43, 611-621.

Gibbs, L. M. and Mosqueda, L. (eds.) (2014). Medical implications of elder abuse and neglect. Clinics in Geriatric Medicine, 30, xv-xvi. DOI: http://dx.doi.org/10.1016/j.cger.2014.08.015.

Glick, J. B. (2005). Protecting and respecting our elders: revising mandatory elder abuse reporting statutes to increase efficacy and preserve autonomy. Virginia fournal of Social Policy \& the Law, 12, 714-743. 
Gondolf, E. W. (2011). The weak evidence for batterer program alternatives. Aggression and Violent Behavior, 16, 347-353. doi:10.1016/j.avb.2011.04.011.

Gorbien, M. J. and Eisenstein, A. R. (2005). Elder abuse and neglect: an overview. Clinics in Geriatric Medicine, 21, 279-292. DOI: http://dx.doi.org/10.1016/ j.cger.2004.12.001.

Greenlee, K. (2011). Statement on Elder Rights and the Older Americans Act before Special Committee on Aging United States Senate. Administration on Aging, US Department of Health and Human Services. http://www.hhs.gov/asl/testify/2011/08/t20110823a.html; last accessed 11 November 2014.

Hafemeister, T. L. (2010). Castles made of sand? rediscovering child abuse and society's response. Ohio Northern University Law Review, 36, 819-913.

Hafemeister, T. L. (2011). If all you have is a hammer: society's ineffective response to intimate partner violence. Catholic University Law Review, 60, 919-1001.

Han, E. L. (2003). Mandatory arrest and no-drop policies: victim empowerment in domestic violence cases. Boston College Third World Law fournal, 23, 159-191.

Harbison, J. (2000). The changing career of "elder abuse and neglect" as a social problem in Canada: learning from feminist frameworks? Fournal of Elder Abuse E Neglect, 11, 59-80. DOI: 10.1300/J084v11n04_05.

Harbison, J. and Morrow, M. (1998). Re-examining the social construction of 'elder abuse and neglect': a Canadian perspective. Ageing E Society, 18, 691-711.

Herring, J. (2012). Elder abuse: a human rights agenda for the future. In I. Doron and A. M. Soden (eds.), Beyond Elder Law: New Directions in Law and Aging (pp. 175-197). Heidelberg: Springer.

Hobbs, F. B. (1996). 65+ in the United States. US Department Commerce \& US Department of Health and Human Services (pp. 2-3). https://www.census.gov/prod/1/pop/p23-190/p23-190.pdf; last accessed 3 December 2014.

Hooyman, N. R. and Kiyak, H. A. (1988). Social Geronotology: A Multidisciplinary Perspective. Boston, MA: Allyn \& Bacon.

Jackson, S. L. (2014). All elder abuse perpetrators are not alike: the heterogeneity of elder abuse perpetrators and implications for intervention. International fournal of Offender Therapy and Comparative Criminology. doi: $10.1177 / 0306624 \mathrm{X} 14554063$.

Jackson, S. L. (2015). The vexing problem of defining financial exploitation occurring in domestic settings. The Fournal of Financial Crime, 21, 63-78. DOI: http://dx.doi.org/10.1108/JFC-05-2014-0026.

Jirik, S. and Sanders, S. (2014). Analysis of elder abuse statutes across the United States, 2011-2012. Fournal of Gerontological Social Work, 57, 478-497. DOI: 10.1080/01634372.2014.884514.

Kelly, J. B. and Johnson, M. P. (2008). Differentiation among types of intimate partner violence: research update and implications for interventions. Family Court Review, 46, 476-499. DOI: 10.1111/j.1744-1617.2008.00215.x.

Kempe, C. H., Silverman, F. N., Steele, B. F., Droegemueller, W. and Silver, H. K. (1962). The battered-child syndrome. $\mathcal{F} A M A, 181,17-24$.
Kohn, N. A. (2009). Outliving civil rights. Washington University Law Review, 86, 1053-1115.

Krienert, J. L., Walsh, J. A. and Turner, M. (2009). Elderly in America: a descriptive study of elder abuse examining national incident-based reporting system (NIBRS) data, 2000-2005. Fournal of Elder Abuse $\mathcal{E}$ Neglect, 21, 325-345. DOI: 10.1080/08946560903005042.

Kutza, E. A. (2005). The intersection of economics and family status in late life: implications for the future. In R. K. Caputo (ed.), Challenges of Aging on US Families: Policy and Practice Implications (pp. 9-26). Binghampton: Haworth.

Lachs, M. S. (1996). Preaching to the unconverted: educating physicians about elder abuse. Fournal of Elder Abuse E Neglect, 7, 1-12. DOI:10.1300/J084v07n04_01.

Lehrner, A. and Allen, N. E. (2009). Still a movement after all these years? current tensions in the domestic violence movement. Violence Against Women, 15, 656-677. DOI: 10.1177/1077801209332185.

Mauer, M. (1999). Why are tough on crime policies so popular. Stanford Law \& Policy Review, 11, 9-21.

McGarry, K. and Schoeni, R. F. (2000). Social security, economic growth, and the rise in elderly widows' independence in the twentieth century. Demography, 37, 221-236.

Miccio, G. K. (2005). A house divided: mandatory arrest, domestic violence, and the conservatization of the battered women's movement. Houston Law Review, 42, 237-323.

Mixson, P. M. (2010). Public policy, elder abuse, and adult protective services: the struggle for coherence. Fournal of Elder Abuse E Neglect, 22, 16-36. DOI: $10.1080 / 08946560903436148$.

O'Shaughnessy, C. V. (2008). The aging services network: broad mandate and increasing responsibilities. Public Policy E Aging Report, 18, 1-19.

Parton, N. (1979). The natural history of child abuse: a study in social problem definition. British fournal of Social Work, 9, 431-451.

Payne, B. K. (2011). Crime and Elder Abuse: An Integrated Perspective, 3rd edn. Springfield, IL: Charles C. Thomas.

Payne, B. K. (2002). An integrated understanding of elder abuse and neglect. Fournal of Criminal Fustice, 30, 535-547. doi: 10.1016/S0047-2352(02)00175-7.

Pillemer, K. (1985). The dangers of dependency: new findings on domestic violence against the elderly. Social Problems, 33, 146-158.

Pizzey, E. (1974). Scream Quietly or the Neighbours will Hear. Middlesex: Penguin Books Ltd.

Rathbone-McCuan, E. (2000). Elder abuse within the context of intimate violence. University of Missouri-Kansas City Law Review, 69, 215-226.

Schechter, S. (1982). Women and Male Violence: The Visions and Struggles of the Battered Women's Movement. Cambridge: South End Press.

Schneider, D. C., Mosqueda, L., Falk, E. and Huba, G. J. (2010). Elder abuse forensic centers. Fournal of Elder Abuse $\mathcal{E}$ Neglect, 22, 255-274. DOI: 10.1080/08946566.2010.490137.

Sherman, L. W. (1992). Influence of criminology on criminal law: evaluating arrests for misdemeanor domestic 
violence. Fournal of Criminal Law E Criminology, 83, $1-45$.

Sherman, L. W. and Berk, R. A. (1984). The specific deterrent effects of arrest for domestic assault. American Sociological Review, 49, 261-271.

Somers, S. (April 2013). INPEA Recognizing and Responding to Elder Abuse. Institute of Medicine, Elder Abuse and Its Prevention, Washington, DC.

Spinetta, J. J. and Rigler, D. (1972). The child-abusing parent: a psychological review. Psychological Bulletin, 77(4), 296-304.

Steinmetz, S. K. (1978). Battered parents. Society, 15, 54-55.

Straus, M. A. and Gelles, R. J. (1986). Societal change and change in family violence from 1975 to 1985 as revealed by two national surveys. Fournal of Marriage and the Family, 48, 465-479.

Teaster, P. B., Wangmo, T. and Anetzberger, G. J. (2010). A glass half full: the dubious history of elder abuse policy. Fournal of Elder Abuse E Neglect, 22, 6-15. DOI: 10.1080/08946560903436130.
Wangmo, et al. (2014). An ecological systems examination of elder abuse: a week in the life of adult protective services. Fournal of Elder Abuse Eo Neglect, 26, 440-457. DOI: $10.1080 / 08946566.2013 .800463$.

Westwood, S. (2012). I may be older, but I can't no "elder.": A critique of "elder law." Temple Policy E Civil Rights Law Review, 21, 485-510.

Wolf, R. (2003). Elder abuse and neglect: history and concepts. In R. J. Bonnie and R. B. Wallace (eds.), Elder Mistreatment: Abuse, Neglect, and Exploitation in an Aging America (pp. 238-248). Washington, DC: National Academies Press.

Wolf, R. S., Hodge, P. and Roberts, P. (1998). Elder abuse and neglect: prosecution and prevention. Critical issues in aging: an annual magazine of the American Society on Aging, 2, 35-38.

Zorza, J. (1992). The criminal law of misdemeanor domestic violence, 1970-1990. The fournal of Criminal Law $\mathcal{F}$ Criminology, 83, 46-72. 